\title{
Selective Depredation of Planted Hardwood Seedlings by Wild Pigs in a Wetland Restoration Area
}

by

J. J. Mayer

Westinghouse Savannah River Company

Savannah River Site

Aiken, South Carolina 29808

E. A. Nelson

L. D. Wike

A document prepared for JOURNAL ARTICLE - ECOLOGICAL ENGINEERING at , , from - .

DOE Contract No. DE-AC09-96SR18500

This paper was prepared in connection with work done under the above contract number with the U.S.

Department of Energy. By acceptance of this paper, the publisher and/or recipient acknowledges the U.S.

Government's right to retain a nonexclusive, royalty-free license in and to any copyright covering this paper, along with the right to reproduce and to authorize others to reproduce all or part of the copyrighted paper. 


\section{DISCLAIMER}

This report was prepared as an account of work sponsored by an agency of the United States Government. Neither the United States Government nor any agency thereof, nor any of their employees, makes any warranty, express or implied, or assumes any legal liability or responsibility for the accuracy, completeness, or usefulness of any information, apparatus, product or process disclosed, or represents that its use would not infringe privately owned rights. Reference herein to any specific commercial product, process or service by trade name, trademark, manufacturer, or otherwise does not necessarily constitute or imply its endorsement, recommendation, or favoring by the United States Government or any agency thereof. The views and opinions of authors expressed herein do not necessarily state or reflect those of the United States Government or any agency thereof.

This report has been reproduced directly from the best available copy.

Available for sale to the public, in paper, from: U.S. Department of Commerce, National Technical Information Service, 5285 Port Royal Road, Springfield, VA 22161

phone: (800) 553-6847

fax: (703) 605-6900

email: orders@ntis.fedworld.gov

online ordering: http://www.ntis.gov/ordering.htm

Available electronically at http://www.doe.gov/bridge

Available for a processing fee to U.S. Department of Energy and its contractors, in paper, from: U.S. Department of Energy, Office of Scientific and Technical Information, P.O. Box 62, Oak Ridge, TN 37831-0062

phone: (865)576-8401

fax: (865)576-5728

email: reports@adonis.osti.gov 


\section{DISCLAIMER}

\section{Portions of this document may be illegible in electronic image products. Images are produced from the best available original document.}




\title{
Selective Depredation of Planted Hardwood Seedlings by Wild Pigs in a Wetland Restoration Area
}

\author{
John J. Mayer ${ }^{a} *$, Eric A. Nelson ${ }^{b}$, and Lynn D. Wike ${ }^{b}$ \\ ${ }^{a}$ Environmental Protection Department, Westinghouse Savannah River Company, P. O. \\ Box 616, Aiken, SC 29808 \\ ${ }^{\mathrm{b}}$ Savannah River Technology Center, Westinghouse Savannah River Company, P. O. \\ Box 616, Aiken, SC 29808 \\ * Corresponding author. Tel.: +1 803 7259575; fax: +1 803 7257673; e-mail: \\ john.mayer@srs.gov
}

\begin{abstract}
Following the planting of several thousand hardwood seedlings in a 69-ha wetland restoration area in west-central South Carolina, wild pigs (Sus scrofa) depredated a large percentage of the young trees. This planting was undertaken as part of a mitigation effort to restore a bottomland hardwood community in the corridor and delta of a third order stream that had been previously impacted by the discharge of heated nuclear reactor effluent. The depredated restoration areas had been pretreated with both herbicide and control burning prior to planting the hardwood seedlings. After discovery of the wild pig damage, these areas were surveyed on foot to assess the magnitude of the depredation on the planted seedling crop. Foraging by the local wild pigs in the pretreatment areas selectively impacted only four of the nine hardwood species used in this restoration effort. Based on the surveys, the remaining five species did not appear to have been impacted at all. A variety of reasons could be used to explain this phenomenon. The pretreatment methodology is thought to have been the primary aspect of the restoration program that initially led the wild pigs to discover the planted seedlings. In addition, it is possible that a combination of other factors associated with odor and taste may have resulted in the selective depredation. Future wetland restoration efforts in areas with wild pigs should consider pretreatment methods and species to be planted. If pretreatment methods and species such as discussed in the present study must be used, then the prior removal of wild pigs from surrounding lands will help prevent depredations by this non-native species.
\end{abstract}

\section{Key Words}

Hardwood seedlings; Wild pigs; Sus scrofa; Depredation; Wetland restoration

\section{Introduction}

Of the various non-native or exotic vertebrates that have been established in the Western Hemisphere, wild pigs (Sus scrofa) are one of the most destructive. At present,

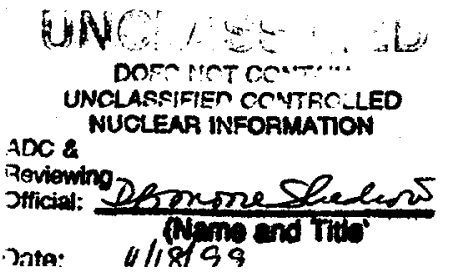


populations of introduced wild pigs exist in 27 states in the United States. Recent estimates have these animals collectively numbering at between two and three million individuals nationwide. Since it's establishment in wild-living populations, this exotic species has become a serious problem in this country because of the damage that it causes to both natural ecosystems and the agricultural industry (Wood and Barrett, 1979; Mayer and Brisbin, 1991; Gipson et al., 1998).

One of the primary types of impacts caused by wild pigs is damage to commercial timber crops. Such impacts can take on a variety of forms including girdling of mature pine trees (Pinus spp.) through rubbing, damage to the lateral roots of mature pine trees by rooting and chewing, and damage to the bark of trees by tusking (i.e., scent marking with the tusk glands) (Conley et al., 1972; Lucas, 1977). However, the most widespread and economically costliest type of forest damage done by wild pigs is the depredation of planted pine seedlings. This has primarily involved longleaf pines $(P$. palustris $)$, slash pines $(P$. elliotti), loblolly pines $(P$. taeda), and pitch pines ( $P$. rigida). Documented from several areas in the southeastern United States (Wahlenberg, 1946; Wakely, 1954; McKnight, 1964; Wood and Lynn, 1977; Belden and Frankenberger; 1977; Lucas, 1977; Wood and Brenneman, 1977.), this type of damage involves the seedlings being pulled out of the ground or rooted up by wild pigs, which then chew up and consume the plant's rootstock and lower portion of the stem. Wild pigs will systematically go from one seedling to the next in one planted row after another in pine regeneration plots, ultimately depredating almost the entire crop (Lucas, 1977; Thompson, 1977; Wood and Brenneman, 1977). During the mid-1900s, in a period of intensive planting of longleaf and slash pine by the U.S. Forest Service, entire pine plantations in Alabama, Florida, Louisiana, and Mississippi were reported to be complete failures because of wild pig depredations (Wahlenberg, 1946; Wakely, 1954; Lucas, 1977).

In contrast to the widespread reports of wild pig damage to planted pine seedlings, there has been little documentation of depredation of hardwood seedlings by wild pigs. Based on a survey, Wood and Lynn (1977) found that wild pig damage to hardwood seedlings was generally considered to be minor to nonexistent by the timber industry in the southeastern United States. However, this survey did not differentiate between naturally regenerated seedlings and planted nursery stock. With respect to that difference, we are aware of no reports in the scientific literature that specifically document the depredation of planted hardwood seedlings by wild pigs.

The Record of Decision (ROD) (DOE, 1991) issued for the final environmental impact statement on the continued operation of K. L., and P Reactors (DOE, 1990) required that the degraded portion of the corridor and delta of Pen Branch, a third order stream located at the Savannah River Site (SRS) in west-central South Carolina (Figure 1), be restored to functional wetlands to the extent possible. The SRS, a $780 \mathrm{~km}^{2}$ federal nuclear facility operated by the U.S. Department of Energy, contains 93 percent forested habitats. The land use is dominated by managed pine plantations. The site is transected by several stream drainage corridors occupied by bottomland hardwood forest and forested swamp (Workman and McLeod, 1990). Between 1954 and 1989, thermal effluent was 
discharged from K Reactor, a nuclear production reactor at the SRS, into the Pen Branch drainage basin. Flooding and elevated temperatures killed the vegetation in the stream corridor and delta. The primary objective of the mitigation directed by the aforementioned ROD was to establish a bottomland hardwood ecosystem in a 69-ha section of the most severely impacted portions of that stream.

Prior to the implementation of the planting program, the upper corridor of Pen Branch was pretreated with a wetland approved herbicide (i.e., Rodeo®) in September 1993 to control the willow (Salix spp.) population and a prescribed burn in November 1993 to clear brush and vines. Planting of the seedlings occurred in December 1993 and January 1994. All seedlings were grown from locally collected seeds in the Georgia State Nursery (see also Nelson et al., this volume). The targeted planting density was 747 trees/ha with a species composition of water oak ( $Q$ uercus nigra, 20\%), water hickory (Carya aquatica, $18 \%$ ), swamp chestnut oak ( $Q$. michauxii, 17\%), cherrybark oak ( $Q$. pagodaefolia, 16\%), green ash (Fraxinus pennsylvanica, 14\%), persimmon (Diospyros virginiana, 7\%), bald cypress (Taxodium distichum, 4\%), swamp tupelo (Nyssa sylvatica var. biflora, 2\%), and water tupelo (Nyssa aquatica, 2\%).

In late January and early February 1994, extensive depredation of these planted seedlings by wild pigs was observed in the upper corridor (Figure 1). Similar to the aforementioned damage to pine seedlings, these hardwood seedlings had been pulled out of the ground and the entire rootstock was either bitten or chewed off. The purpose of the present study was to document this rarely reported type of damage by wild pigs and to quantify any differences among the hardwood species involved in this restoration effort.

\section{Methods}

The damage was restricted to the pretreated portions (i.e., herbicided and control burned) of the upper corridor of the restoration area; therefore, the present study was limited to that portion of the Pen Branch corridor. Although wild pigs were observed throughout the Pen Branch wetland restoration area, no damage was noted to any of the planted seedlings in either the control areas or the delta. Pedestrian surveys of planted pretreated areas B (10.8 ha) and D (4.3 ha) were conducted in February and March of 1994 to determine the extent of the wild pig damage to the hardwood seedlings (Figure 1). On two separate sampling efforts, four people walked in parallel transects down the lengths of the pretreated areas, spaced relatively evenly apart across the width of the upper corridor. The second sampling effort began where the first effort ended, such that the sampling collectively constituted one continuous survey over the sampled portions of the upper corridor. The presence of both impacted and intact seedlings were noted along these transects. Species tallies were then compiled from the four transects in the surveyed areas. Chi-square analyses were used to determine if differences between the numbers of each species impacted were significant. 


\section{Results}

Of the nine hardwood species used in the planting effort, only cherrybark oak, swamp chestnut oak, water hickory, and swamp tupelo were impacted by the wild pig foraging activities. None of the remaining species were found to have been depredated. This difference in depredation among the nine species was significant $\left(\chi^{2}=934.51 ;\right.$ d.f. $=8$; $p<0.001)$. The pedestrian surveys resulted in a total of 388 seedlings of the four impacted species being found. This represented approximately 7.1 percent of the estimated total number of seedlings belonging to these four species that had been planted earlier in the two areas sampled in the upper corridor. Out of the aforementioned total, 245 seedlings had been depredated by wild pigs. The percentage of impacted trees to total numbers of each species found were as follows: cherrybark oak - 69.7\%, swamp chestnut oak $50.0 \%$, water hickory $-34.3 \%$, and swamp tupelo $-10.0 \%$. The difference between numbers of impacted seedlings among these four species was also significant $\left(\chi^{2}=380.14\right.$; d.f. $=3 ; p<0.001$ ). Among the depredated species, the cherrybark oak, swamp chestnut oak, and swamp tupelo had been pulled or rooted up and the rootstock was consumed. The impacted water hickory seedlings had been pulled out of the ground, but the rootstocks were left completely intact by the foraging pigs.

Similar to wild pig depredation of planted pine seedlings, the hardwood seedlings were uprooted, fed upon, and then dropped immediately adjacent to the spot where they had been planted. In addition, the Pen Branch animals seemed to use the same strategy of following the planted rows of seedlings, going from one hardwood seedling to the next. The pigs further appeared to follow the routes through the cleared understory that had been taken by the contracted crew who initially planted the seedlings, uprooting and feeding upon long linear series of the planted hardwoods for extended distances. This was especially true for the planted lines of both cherrybark and swamp chestnut oaks. Based on the size of the tracks found in the impacted areas, both adult and immature wild pigs appear to have been involved in these impacts. In addition, both solitary wild pigs and groups of these animals were variously observed in the upper corridor at the time of the seedling depredations.

\section{Discussion}

Wild pigs are opportunistic foragers that are omnivorous in their widely variable food habits (Sweeney and Sweeney, 1982). In spite of using both floral and fauna resources in their diet, wild pigs have a decided preference for plant material for most of the year (Conley et al., 1972; Scott and Pelton, 1975; Barrett, 1978; Wood and Roark, 1980). It would not be surprising then, that when presented with the right circumstances, these animals will probably feed on most types of pine or hardwood seedlings that they might encounter on the SRS.

Depredation of pine seedlings by wild pigs has occurred at the SRS since the mid-1950s (Tofte, 1959; Jenkins and Provost, 1964; Hatcher, 1966; Beaver et al., 1973). In spite of this past history, wild pig damage to timber regeneration has generally not been 
considered to be important at either the SRS or throughout the rest of the South in recent times. In part, this is because relatively little longleaf pine (i.e., the most impacted species of pine) has been regenerated recently on a commercial scale (Wood and Lynn, 1977; Wood and Brenneman, 1977).

By comparison with the historical magnitude of the depredation of pine seedlings by wild pigs, the overall impact to the planted hardwood seedlings in the wetland restoration area was minor. In the $1940 \mathrm{~s}-50 \mathrm{~s}$, it was estimated within the Southeast that wild pigs were destroying several hundred acres of longleaf pine plantation per day. Individual animals were observed to wipe out an acre of planted pines in a single day (Wahlenberg, 1946; McKnight, 1964). A comparable level of depredation as seen in these early pine regeneration plots would have completely destroyed the planted seedlings in the pretreatment areas. Apparently, hardwood seedlings are not as highly favored as longleaf pine among wild pigs as food resources.

Why certain hardwood seedlings used in the restoration effort were depredated while others were not is uncertain. Among pines, longleaf seedlings are preferred because of the more extensive cambium layer compared to other pine species (Wood and Lynn, 1977; R. Bonar, pers. comm.). Perhaps the hardwood species that were depredated had more aromatic constituents than the non-impacted species, thereby making them more attractive to the pig's highly developed or acute sense of smell. It is also possible that the odor of freshly overturned or disturbed soil around the seedlings may have been an attractant for the pigs to investigate each spot. However, this does not explain why the wild pig foraging in the recently planted pretreatment areas did not impact seedlings of the other five species present.

The fact that the seedlings were nursery stock as opposed to being naturally regenerated may also have led to the wild pigs seeking the young trees out and feeding on them. Preference for nursery stock over natural seedlings by elk (Cervus elaphus canadensis) and mule deer (Odocoileous hemionus) has been observed in areas of the western United States, where both types of seedlings occur in the same regeneration area ( $R$. Bonar, pers. comm.). Seedling quality has received considerable attention in the last decade among nursery managers. Seedling parameters that correlate with field performance have been examined, and nursery practices established to produce these attributes. One that has received considerable attention is root morphology and volume. Growing conditions to increase plantable root volume are now common in Southeastern nurseries (Rose and Haase, 1995). To produce this, optimal growing conditions of nutrition and water management for the seedlings are maintained for much of the growing season in the nursery beds prior to dormancy induction. This results in larger root volumes and increased starch and sugar levels at the time of lifting and transplanting to the field. Because of this accelerated growth, root tissue is often more succulent when transplanted than corresponding root mass in a natural seedling. Again, however, this does not explain the selective depredation among the nine species of hardwood nursery stock. 
The depredations were restricted to the cleared pretreatment areas (i.e., Areas B and D). The readily available access within these areas and the unobstructed locations of the planted seedlings may have been one of the main contributing factors to these depredations. Similar depredation of planted conifer seedlings by elk has been observed in areas burned by wildfires in the western United States. However, if such restoration planting was postponed until new growth became established in the burned areas, then depredations by the elk were virtually eliminated (R. Bonar, pers. comm.). In addition, Miller et al. (1982) found that conspicuously planted saplings were more liable to browsing by red deer (C. e. elaphus) in an open range area of eastern Scotland. Along the same line of reasoning, the impacted pretreatment areas of the upper corridor were replanted in January 1995 following the recovery of a vigorous herbaceous understory during the second growing season. Although wild pigs were still present in the surrounding area (i.e., based on sightings of live animals and presence of field sign such as rooting and tracks), no more depredations were observed after the replanting.

The ultimate explanation for this unusual depredation may involve a combination of the aforementioned factors. It is likely that the pretreatment methods employed enabled the pigs easy access through these cleared portions of the upper corridor. The smell of the recently disturbed soil may have drawn the pigs to investigate the individual seedlings. Lastly, some as of yet undetermined element led to the selective depredation of four of the nine hardwood species present in the pretreatment areas.

Finally, it should be noted that the removal of 30 wild pigs by the SRS wild pig control subcontractor from the area immediately surrounding the Pen Branch corridor in the early Spring of 1994 eliminated further depredations of the remaining hardwood seedlings in the pretreatment areas that year. Consistent with the observations and field sign, those individuals removed from the Pen Branch area variously included adult and immature animals of both sexes. Similar removals of wild pigs around longleaf pine regeneration plots have also succeeded in suppressing further seedling depredation by these animals (Wood and Brenneman, 1977).

\section{Conclusion}

The pretreatment (i.e., clearing and burning) of the planting areas appeared to have induced severe depredation by wild pigs in the upper corridor of the Pen Branch wetland restoration area. Among the impacted seedlings, there was an apparent preference for certain species, especially the cherrybark oak and swamp chestnut oak. The removal of a number of wild pigs from the area encompassing the Pen Branch corridor also seemed to eliminate any further impacts to the remaining or subsequently planted seedlings in the restoration area. Replanting seedlings in the impacted areas after the recovery of the herbaceous understory resulted in no more wild pig depredations in the restoration area.

Planning for future wetland restoration efforts in areas inhabited by wild pig populations should take pretreatment methods and species to be planted into consideration. If methods and species similar to those discussed in the present study are the only 
alternative with respect to implementing specific wetland restoration objectives, then a concerted effort to remove wild pigs from the areas encompassing the project location should be conducted prior to the planting of any hardwood seedlings.

\section{Acknowledgements}

The efforts of W. M. Fulmer, who participated in the pedestrian surveys along with the three authors to quantify the impact of this depredation, are very much appreciated. F. D. Martin and I. L. Brisbin, Jr. critically read earlier drafts of the manuscript. This study was supported through funding provided by the U.S. Department of Energy to the Westinghouse Savannah River Company under contract DE-AC09-96SR18500. 


\section{References}

Barrett RH. The feral hog on the Dye Creek Ranch, California. Hilgardia 1978;46: 283355.

Beaver JR, Hensley CW, Byrne JG, Clebsch EEC, Jenkins JH. Opportunities for Resource Management at the Savannah River Plant: an Ecological Analysis. U. S. Forest Service, Southern Region, Atlanta, Georgia. 1973, 28 pp.

Belden RC, Frankenberger WB. Management of feral hogs in Florida - past, present, and future. In: Wood GW, editor. Research and Management of Wild Hog Populations. Belle Baruch Forest Science Institute, Clemson Univ. Georgetown, South Carolina. 1977: 5-10.

Conley RH, Henry VG, Matschke GH. Final Report for the European Wild Hog Research Project W-34, Tennessee Game \& Fish Commission, Nashville, Tennessee. 1972, 259 pp.

DOE (U. S. Department of Energy). Final Environmental Impact Statement: Continued Operation of K. L. and P Reactors at the Savannah River Site, DOE/EIS-0147, Savannah River Operations Office, Aiken, South Carolina. 1990, five chapters, pagination by chapter.

DOE (U. S. Department of Energy). Record of Decision: Continued Operation of K. L. and P Reactors at the Savannah River Site, Aiken, SC. Federal Register 1991;58:5584-5587.

Gipson PS, Hlavachick B, Berger T. Range expansion by wild hogs across the central United States. Wildl Soc Bull 1998;26:279-286.

Hatcher J. History of the Savannah River Project - Atomic Energy Commission 19511966. U.S.D.A., U. S. Forest Service, Savannah River Forest Station, Aiken, South Carolina. 1966, 39 pp.

Jenkins J H, Provost EE. The Population Status of the Larger Vertebrates on the Atomic Energy Commission Savannah River Plant Site. Publication Office of Technical Services, Department of Commerce, Washington, DC. 1964, 45 pp.

Lucas EG. Feral hogs - problems and control on national forest lands. In: Wood GW, editor. Research and Management of Wild Hog Populations. Belle Baruch Forest Science Institute, Clemson Univ. Geórgetown, South Carolina. 1977: 17-21.

Mayer JJ, Brisbin Jr IL. Wild Pigs in the United States: Their History, Morphology and Current Status. The University of Georgia Press, Athens, Georgia. 1991, 313 pp. 
McKnight T. Feral livestock in Anglo-America. University of California, Publ Geol 1964;16:1-87.

Miller GR, Kinnard JW, Cummins RP. Liability of saplings to browsing on a red deer range in the Scottish highlands. J Appl Ecol 1982:19:941-951.

Rose R, Haase DL. The target seedling: implementing a program. In: Landis TL, Cregg B, editors. National Proceedings, Forest and Conservation Nursery Assoc., U.S. Forest Service, Gen. Tech. Rep. PNW-GTR-365, 1995:124-130.

Scott CD, Pelton MR. Seasonal food habits of the European wild hog in the Great Smoky Mountains National Park. Proc Ann Conf SE Assoc Fish \& Wildl Agen 1975;29:585593.

Sweeney JM, Sweeney JR. Feral hog. In: Chapman JA, Feldhammer GA, editors. Wild Mammals of North America: Biology, Management, and Economics. The Johns Hopkins Univ Press, Baltimore, Maryland. 1982:1099-1113.

Thompson RL. Feral hogs on national wildlife refuges. In: Wood GW, editor. Research and Management of Wild Hog Populations. Belle Baruch Forest Science Institute, Clemson Univ. Georgetown, South Carolina. 1977:11-15.

Tofte AL. Report on the Land Management Program - Savannah River Operations Office, Vol. II. U.S.D.A., U. S. Forest Service, Savannah River Forest Station, Aiken, South Carolina. 1959, 44 pp.

Wahlenberg WG. The Longleaf Pine. C. L. Pack Forestry Foundation, Washington, DC. $1946,429 \mathrm{pp}$.

Wakely PC. Planting the Southern Pine. For Serv Agricul Monog 1954;18:1-233.

Wood GW, Barrett RH. Status of wild pigs in the United States. Wildl Soc Bull 1979;7:237-246.

Wood GW, Brenneman RE. Research and management of feral hogs on Hobcaw Barony. In: Wood GW, editor. Research and Management of Wild Hog Populations. Belle Baruch Forest Science Institute, Clemson Univ. Georgetown, South Carolina. 1977: 23-35.

Wood GW, Lynn Jr TE. Wild hogs in southern forests. South J Appl For 1977;1:12-17.

Wood GW, Roark DN. Food Habits of feral hogs in coastal South Carolina. J Wildl Manage 1980;44:506-511. 
Workman SW, McLeod KW. Vegetation of the Savannah River Site. SRO-NERP-19. Savannah River Ecology Laboratory, Aiken, South Carolina. 1990, 137 pp. 
WSRC-TR-99-00408

Oct. 25, 1999

\section{Figure Captions}

Figure 1. Location of the pretreatment areas surveyed for wild pig depredation impacts in the Pen Branch Wetland Restoration Area at the U.S. Department of Energy's Savannah River Site, South Carolina.

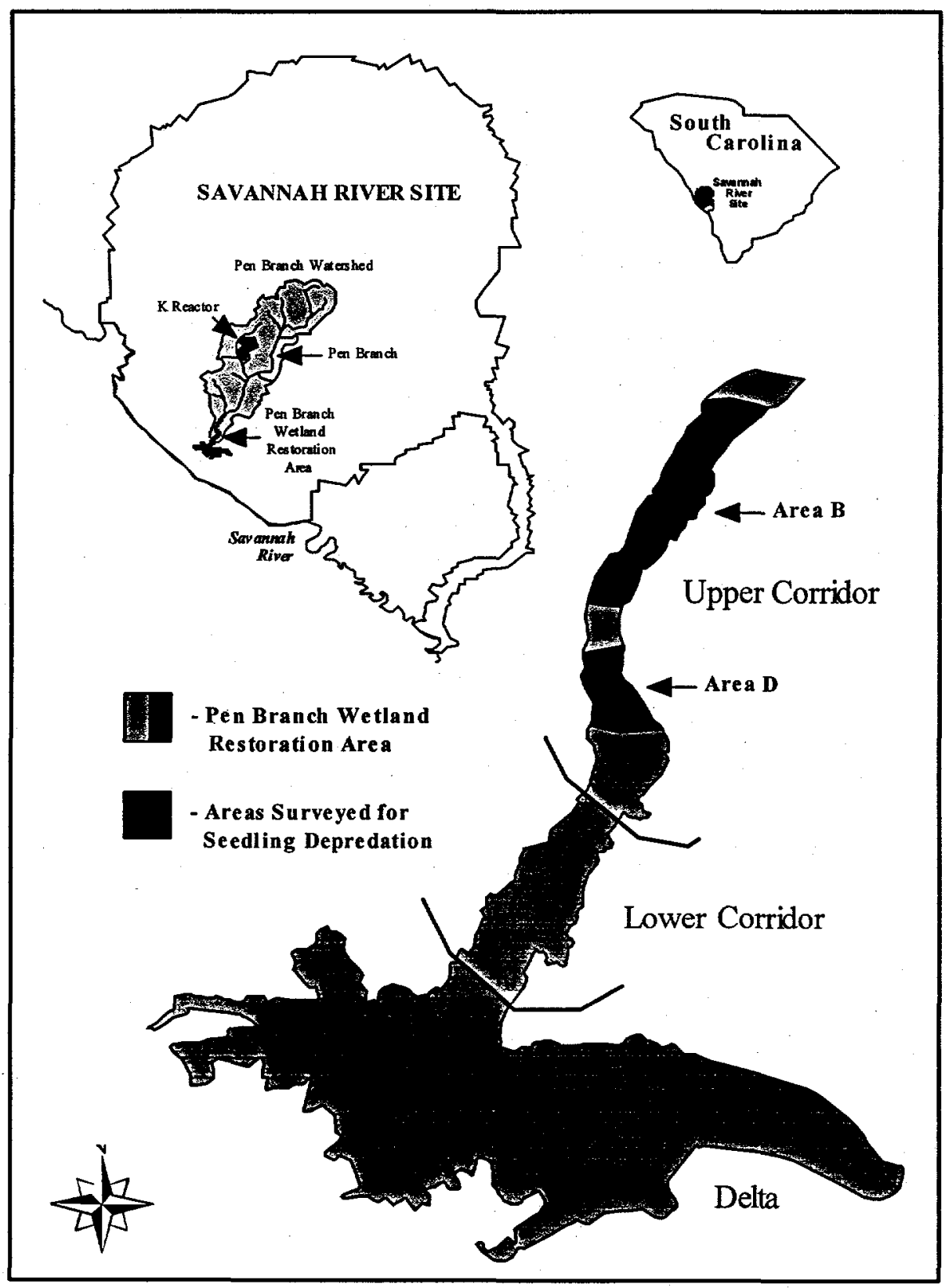

